\section{7}

8

9

\title{
Effect of acidic electrolyzed water-induced bacterial inhibition and injury in live clam (Venerupis philippinarum) and mussel (Mytilus edulis)
}

Hamzah M. Al-Qadiri ${ }^{\mathrm{a}}$, Murad A. Al-Holy ${ }^{\mathrm{b}}$, Setareh Ghorban Shiroodi ${ }^{\mathrm{a}}$, Mahmoudreza $^{2}$

Ovissipour $^{\mathrm{a}, \mathrm{c}, *}$, Byju N. Govindan ${ }^{\mathrm{c}}$, Nivin Al-Alami $^{\mathrm{d}}$, Shyam S. Sablani ${ }^{\mathrm{c}}$ Barbara Rasco $^{\mathrm{a}}$

${ }^{a}$ School of Food Science, Washington State University, Pullman, WA 99164, USA

${ }^{b}$ Department of Clinical Nutrition and Dietetics, Faculty of Allied Health Sciences, Hashemite University, P.O Box 150459, Zarqa 13115, Jordan

${ }^{c}$ Department of Biological Systems Engineering, Washington State University, Pullman, WA 99164, USA

${ }^{d}$ Water, Energy and Environment Center, The University of Jordan, Amman 11942 Jordan

\section{Running Title: Acidic electrolyzed water-induced bacterial inhibition and injury}

*Corresponding author. Tel: +1 509335 3843; Fax: +1 5093354815.

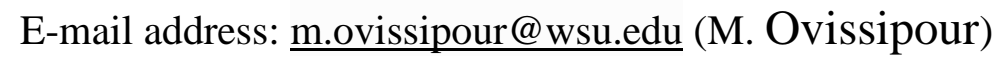


21 The effect of acidic electrolyzed water (AEW) on inactivating Escherichia coli O104:H4, Listeria monocytogenes, Aeromonas hydrophila, Vibrio parahaemolyticus and Campylobacter jejuni in

23 laboratory contaminated live clam (Venerupis philippinarum) and mussel (Mytilus edulis) was

24 investigated. The initial levels of bacterial contamination were: in clam 4.9 to $5.7 \log _{10} \mathrm{CFU} / \mathrm{g}$, and 25 in mussel 5.1 to $5.5 \log _{10} \mathrm{CFU} / \mathrm{g}$. Two types of AEW were used for treatment time intervals of 1 and $2 \mathrm{~h}$ : strong (SAEW) with an available chlorine concentration (ACC) of $20 \mathrm{mg} / \mathrm{L}, \mathrm{pH}=3.1$, and an oxidation-reduction potential (ORP) of $1150 \mathrm{mV}$, and weak (WAEW) at ACC of $10 \mathrm{mg} / \mathrm{L}, \mathrm{pH}=$ 3.55 and ORP of $950 \mathrm{mV}$. SAEW and WAEW exhibited significant inhibitory activity against inoculated bacteria in both shellfish species with significant differences compared to saline solutions treatments $(1-2 \% \mathrm{NaCl})$ and untreated controls $(0 \mathrm{~h})$. SAEW showed the largest inhibitory activity, the extent of reduction $\left(\log _{10} \mathrm{CFU} / \mathrm{g}\right)$ ranged from 1.4-1.7 for E. coli O104:H4; 1.0-1.6 for L. monocytogenes; 1.3-1.6 for A. hydrophila; 1.0-1.5 for V. parahaemolyticus; and 1.5-2.2 for $C$. jejuni in both types of shellfish. In comparison, significantly $(P<0.05)$ lower inhibitory effect of WAEW was achieved compared to SAEW, where the extent of reduction $\left(\log _{10} \mathrm{CFU} / \mathrm{g}\right)$ ranged from 0.7-1.1 for E. coli O104:H4; 0.6-0.9 for L. monocytogenes; 0.6-1.3 for A. hydrophila; 0.7-1.3 for V. parahaemolyticus; and 0.8-1.9 for C. jejuni in both types of shellfish. Among all bacterial

37 strains examined in this study, AEW induced less bacterial injury $\left(\sim 0.1-1.0 \log _{10} \mathrm{CFU} / \mathrm{g}\right)$ and more inactivation effect. This study revealed that AEW (10-20 mg/L ACC) could be used to reduce bacterial contamination in live clam and mussel, which may help control possible unhygienic practices during production and processing of shellfish without apparent changes in the quality of 41 the shellfish.

42 Keywords: Acidic electrolyzed water, Clam, Mussel, Bacterial injury. 


\section{Introduction}

Foodborne bacterial outbreaks due to the consumption of contaminated shellfish may

71 impose significant health and economic threats. There are several sources of contamination by 72 pathogenic bacteria during the production and processing of shellfish; these may include the 73 microbial pollution of the aquatic environment itself and shellfish-growing waters, which is a major 74 common concern in marine coastal areas (Almeida and Soares, 2012; Schulze et al., 2006). Other 75 potential sources of bacterial contamination could be linked to the shellfish indigenous microbiota, 76 the bacteria naturally present in marine and estuarine environments (e.g., Vibrio spp., Listeria 77 monocytogenes and Aeromonas hydrophila); non-indigenous enteric bacteria due to fecal 78 contamination (e.g., Escherichia coli and Campylobacter spp.); and bacterial pollution due to 79 unhygienic processing and preparation by producers and consumers (Anacleto et al., 2013; Croci et al., 2007; Reilly and Käferstein, 1997). As a result, raw molluscan shellfish is considered a major

81 health risk, in which the main route of bacterial transmission to humans includes the consumption 82 of raw and lightly cooked shellfish (Lees et al., 2010; Newton et al., 2014; Quan et al., 2010).

The clam (Venerupis philippinarum) is one of the most commercially important aquaculture 84 shellfish species and has an important socioeconomic aspect because it is easily grown and 85 harvested and has a good nutritional value (Oliveira et al., 2011; Park et al., 2006; Zhang et al., 86 2015). The blue mussel (Mytilus edulis) is a euryhaline and eurythermal shellfish cultivated in 87 intensive aquaculture (Innes and Bates, 1999) and is usually consumed raw, smoked or canned.

88 These two bivalve shellfish feed by filtering large quantities of water and can accumulate bacteria 89 from the aquatic environment (Anacleto et al., 2013; Love et al., 2010; Ovissipour et al., 2013).

The worldwide demand for freshly live, whole, high-quality and microbiologically safe 91 shellfish is increasing. Therefore, having effective nontoxic disinfection treatments to control 
92 bacterial contamination and extend the shelf life of perishable shellfish is a major requirement.

93 Technically, the USA National Shellfish Sanitation Program (NSSP) suggests three methods for

94 cleansing and decontamination of shellfish: transfer of shellfish to natural waters for more than 14

95 days at an appropriate salinity and temperature ranges; depuration in a verified system for more

96 than $44 \mathrm{~h}$; and pasteurization by heat or high pressure (Love et al., 2010; Ovissipour et al., 2013;

97 Ren and $\mathrm{Su}, 2006)$. However, most of these treatments require significant personnel training; a 98 considerable initial investment in capital for depuration tanks, etc., and the proposed

99 decontamination treatment is not always effective against microorganisms that colonize the 100 intestinal tract of the shellfish (Ren and $\mathrm{Su}, 2006$ ). Due to its bactericidal properties, electrolyzed 101 oxidizing water (EO water) could be used to control bacterial contamination in shellfish as a non102 thermal post harvest sanitation treatment method. EO water involves electrolysis of deionized water 103 containing sodium chloride in an electrolytic chamber with a diaphragm separating the anode from 104 the cathode. Acidic electrolyzed water (AEW) is produced at the anode with a $\mathrm{pH}$ of less than 3.5, 105 an oxidation-reduction potential (ORP) greater than $1000 \mathrm{mV}$, and available chlorine concentration 106 (ACC) of 10-250 mg/L (Ovissipour et al., 2015). The pH, ORP and ACC of the acidic EO water 107 depend upon the sodium chloride concentration, electrolysis time, and water flow into the 108 electrolysis chamber (Hsu, 2003; Ovissipour et al., 2015; Venkitanarayanan et al., 1999). The use of 109 strong and weak EO water as an antimicrobial solution with high and low ACC has been studied in 110 bacterial cell suspensions (Ovissipour et al., 2015; Quan et al., 2010); to reduce bacterial 111 contamination of Vibrio spp. in raw oyster and shrimp (Ren and Su, 2006; Xie et al., 2012) or to 112 study the disinfectant effect in inoculated fish and fish surface (Al-Holy and Rasco, 2015; Huang et 113 al., 2006; Kasai et al., 2000; Shiroodi et al., 2016). However, in most previously reported research, 114 treatment regimes using high chlorine concentrations (>30 mg/L) with prolonged exposure time 
115 (> $2 \mathrm{~h}$ ) were applied to study the antimicrobial properties of EO water, levels at which significant deterioration in the quality of the fish or shellfish would occur and which may not be legal.

The objective of the current study was to investigate the inhibitory activity and injury of AEW (ACC of 10 and $20 \mathrm{mg} / \mathrm{L}$ ) against Escherichia coli O104:H4, Listeria monocytogenes, Aeromonas hydrophila, Vibrio parahaemolyticus and Campylobacter jejuni that had been separately inoculated into the live shellfish through feeding activity.

\section{Materials and methods}

\subsection{Bacterial strains and growth conditions}

All bacterial American Type Culture Collection (ATCC) strains were obtained from Microbiologics, Inc. (St. Cloud, MN). Escherichia coli O104:H4 ATCC BAA-2326, Listeria monocytogenes ATCC 19111, and Aeromonas hydrophila ATCC 35654 were cultured and activated by inoculating each specific Kwik-Stik swab (Microbiologics, Inc.) into $100 \mathrm{~mL}$ of tryptic soy broth TSB (Difco ${ }^{\mathrm{TM}}$ ) and then were incubated at $37^{\circ} \mathrm{C}$ for $24 \mathrm{~h}$. All strains were cultured to yield a cell count of approximately $10^{9} \mathrm{CFU} / \mathrm{mL}$. E. coli, L. monocytogenes and A. hydrophila suspensions were enumerated in duplicate using the spread-plate technique in which a 1-mL aliquot of each dilution was divided into 5 aliquots of $0.2 \mathrm{~mL}$ and cultured on tryptic soy agar TSA (Difco TM) (Al-Qadiri et al., 2015; Ovissipour et al., 2015). Vibrio parahaemolyticus ATCC 17802 was activated by inoculating the Kwik-Stik swab into $100 \mathrm{~mL}$ of TSB (Difco ${ }^{\mathrm{TM}}$ ) supplemented with $2 \%$ $\mathrm{NaCl}$ followed by incubation at $37{ }^{\circ} \mathrm{C}$ for $24 \mathrm{~h}$ (Ovissipour et al., 2015). Campylobacter jejuni ATCC 29428 was activated by inoculating the Kwik-Stik swab into $100 \mathrm{~mL}$ of Campylobacter enrichment broth consisting of Campylobacter nutrient broth no. 2 (CM0067, Oxoid Ltd.) and supplemented with Campylobacter growth supplement (SR0232E, Oxoid Ltd.). C. jejuni broth was 
138 then incubated in an anaerobic jar at $37^{\circ} \mathrm{C}$ for $48 \mathrm{~h}$ under a microaerophilic atmosphere $(\sim 6$ to $7 \%$

$139 \mathrm{O}_{2}$ ) using CampyGen sachets (CN0025, Oxoid Ltd.) (Al-Qadiri et al., 2015). V. parahaemolyticus

140 and $C$. jejuni were cultured to obtain a cell count of approximately $10^{9} \mathrm{CFU} / \mathrm{mL}$, thereafter, they

141 were enumerated in duplicate using the spread-plate technique in which a 1-mL aliquot of each

142 dilution was divided into 5 aliquots of $0.2 \mathrm{~mL}$ and cultured on TSA (Difco ${ }^{\mathrm{TM}}$ ) supplemented with

$1432 \% \mathrm{NaCl}$ and Campylobacter blood-free medium (modified CCDA Preston, CM0739, Oxoid Ltd.),

144 respectively (Al-Qadiri et al., 2015; Astorga and Alonso, 2010; Ovissipour et al., 2015).

145 2.2. Inoculum preparation

146 After the appropriate incubation of bacterial cultures, $50 \mathrm{~mL}$ broth of each strain was

147 transferred under aseptic conditions to a sterile centrifuge tube and centrifuged for 15 min at 5000

$148 \mathrm{rpm}(3380 \times g)$ to harvest bacterial cells (AccuSpin Centrifuge, Thermo Fisher Scientific, Waltham,

149 MA). To eliminate the effect of broth components and bacterial metabolites, the resultant pellets

150 were resuspended in $50 \mathrm{~mL}$ of sterile saline solution $(0.85 \%(\mathrm{wt} / \mathrm{vol}) \mathrm{NaCl})$. The tubes were then

151 centrifuged as before, and the resulting pellets of the five strains were then resuspended in $50-\mathrm{mL}$

152 aliquots and centrifuged for a second time as described above. The supernatant was decanted and

153 the resulting washed pellets were resuspended in sterile $50-\mathrm{mL}$ aliquots, which were then used to

154 inoculate the live shellfish samples. The initial bacterial load for all bacterial types inoculated into

155 clam and mussel ranged between $7.3 \times 10^{4}$ to $5.0 \times 10^{5} \mathrm{CFU} / \mathrm{g}$.

156 2.3. Preparation of acidic electrolyzed water

157 Acidic electrolyzed water (AEW) was prepared from the anode compartment in the 158 electrolytic cell in which EO water was generated at 9-12 V direct current (DC) for 15 min using a 159 two-compartment batch scale electrolysis apparatus (Super Oxseed Labo, Electrolyzed Water 160 Generator, Aoi Electronic Corp., Kannami, Shizuoka, Japan) with the anode and cathode electrodes 
161 of the chamber divided by an ion exchange diaphragm. The ORP and $\mathrm{pH}$ were measured using a 162 pocket sized redox meter (HI 98201, HANNA ${ }^{\circledR}$ Instruments, Ann Arbor, Michigan, USA) and a pH 163 meter (FE20, Mettler-Toledo, Columbus, OH, USA), respectively. The available chlorine 164 concentration of the generated AEW was measured using the DPD assay method (Colorimeter ${ }^{\mathrm{TM}}$ 165 Analysis System, Hach Co., Loveland, CO, USA) according to the manufacturer instructions. Two 166 types of AEW were prepared (Ovissipour et al., 2015): strong (SAEW: $200 \mathrm{mg} / \mathrm{L} \mathrm{NaCl,} \mathrm{pH}=3.1$, $167 \mathrm{ORP}=1150 \mathrm{mV}$, and $\mathrm{ACC}=20 \mathrm{mg} / \mathrm{L}$ ) and weak (WAEW: $40 \mathrm{mg} / \mathrm{L} \mathrm{NaCl}, \mathrm{pH}=3.55, \mathrm{ORP}=950$ $168 \mathrm{mV}$, and $\mathrm{ACC}=10 \mathrm{mg} / \mathrm{L})$.

\section{2.4. Sample preparation and inoculation process}

Live clam (Venerupis philippinarum) and mussel (Mytilus edulis) were purchased from a

171 local retailer in Pullman, WA, and transferred to the laboratory under cold conditions within 30 172 min. The purchased shellfish were examined for free residual chlorine (DPD assay method) and 173 found to be in the range of $2-4 \mathrm{mg} / \mathrm{L}$. Clams and mussel samples were treated separately, first by 174 soaking for $2 \mathrm{~h}$ in freshly prepared sterile sodium thiosulfate solution ( $2 \%(\mathrm{wt} / \mathrm{vol}) \mathrm{Na}_{2} \mathrm{~S}_{2} \mathrm{O}_{3}$ ) to 175 neutralize any residual chlorine at ambient temperature $\left(22^{\circ} \mathrm{C}\right)$. This was done to preclude any 176 external inhibitory effect besides the treatments applied in the current study. During the 177 dechlorination process, any dead clams and mussels were separated from the live ones with the 178 presumption made that any animals with an open shell were dead. After $2 \mathrm{~h}$, sodium thiosulfate 179 solution was decanted and the shellfish were soaked for $1 \mathrm{~h}$ in a freshly prepared sterile saline 180 solution $(1 \%(\mathrm{wt} / \mathrm{vol}) \mathrm{NaCl})$ at ambient temperature. Following this and under aseptic conditions, 181 the live shellfish were placed into a freshly prepared sterile saline solution ( $1 \%(\mathrm{wt} / \mathrm{vol}) \mathrm{NaCl})$ for 182 all microbes with the exception of $V$. parahaemolyticus in which case $2 \% \mathrm{NaCl}$ was used with a 183 ratio of 1 animal per $100 \mathrm{~mL}$ solution. For each treatment, 25 live clams or 30 live mussels were 
184 inoculated separately with each of the bacterial strains to be tested. The 50-mL aliquot of the 185 bacterial culture previously described was separately added to the solution containing the live 186 shellfish with the approximate bacterial concentration being $10^{7} \mathrm{CFU} / \mathrm{mL}$. The shellfish samples 187 were held in the inoculated saline for $6 \mathrm{~h}$ at ambient temperature to let bacteria adhere to the exposed surfaces and to allow the shellfish to filter the water so that the bacteria would become a component of the digestive tract. At the end of the incubation process, the inoculated shellfish were 190 aseptically recovered and placed into containers of freshly prepared SAEW (ACC $=20 \mathrm{mg} / \mathrm{L})$ or WAEW $(\mathrm{ACC}=10 \mathrm{mg} / \mathrm{L})$ with a ratio of 1 animal per $100 \mathrm{~mL}$ solution and for depuration times of 1 and $2 \mathrm{~h}$. The used AEW contained $1 \%$ (wt/vol) $\mathrm{NaCl}(2 \%$ in case of $V$. parahaemolyticus) to minimize bacterial osmotic stresses and to promote filtration activity of the shellfish. Inoculated

194 shellfish not treated with SAEW or WAEW served as controls $(0 \mathrm{~h})$. Second control treatments of 195 inoculated shellfish were held in $1 \%$ (wt/vol) $\mathrm{NaCl}(2 \%$ in case of $V$. parahaemolyticus) instead of AEW, samples were treated as above for depuration times of 1 and $2 \mathrm{~h}$. All tests were carried out in 197 triplicate.

\subsection{Recovery of bacteria and culture media}

To recover the surviving bacteria, shellfish were shucked under aseptic conditions, weighed 200 and examined in duplicate using selective and nonselective culture media. The shellfish flesh was 201 placed in sterile strainer-filter bags and shaken vigorously in $200 \mathrm{ml}$ of sterile D/E Neutralizing 202 Broth (Difco ${ }^{\mathrm{TM}}$ ) using a Stomacher 400 circulator (Seward Ltd., London, UK). One milliliter of the 203 stomached suspension was then serially diluted (dilution range, $10^{0}$ to $10^{-5}$ ) in $9 \mathrm{~mL}$ of sterile $0.1 \%$ 204 peptone water $\left(\right.$ Difco $\left.^{\mathrm{TM}}\right)$. Samples were examined in duplicate using the spread-plate technique. A $2051-\mathrm{mL}$ aliquot of each dilution was divided into 5 aliquots of $0.2 \mathrm{~mL}$, which then they were evenly 206 spread on the following selective culture media for enumeration of $E$. coli O104:H4, $L$. 
monocytogenes, A. hydrophila, and V. parahaemolyticus, respectively: m-Endo agar LES (Difco ${ }^{\mathrm{TM}}$ ) (Al-Qadiri et al., 2011), PALCAM agar supplemented with required antibiotics (CM0877, Oxoid Ltd.) (Liu and Busse, 2010), Aeromonas medium (RYAN) (CM0833, Oxoid Ltd) (Warburton et al., 1994) and Cholera medium TCBS (CM0333, Oxoid Ltd.) (Hara-Kudo et al., 2001). Plates were then incubated at $37{ }^{\circ} \mathrm{C}$ for $24-48 \mathrm{~h}$, and the number of viable cells was determined as $\mathrm{CFU} / \mathrm{g}$. Selective Campylobacter blood-free medium (modified CCDA Preston), which was prepared with the addition of CCDA selective supplement (SR0155, Oxoid Ltd.), was used to enumerate surviving C. jejuni (Astorga and Alonso, 2010). Plates were then incubated at $37{ }^{\circ} \mathrm{C}$ for $48 \mathrm{~h}$ under microaerophilic conditions. TSA $\left(\operatorname{Difco}^{\mathrm{TM}}\right)$ was used as a nonselective culture medium with the addition of $2 \% \mathrm{NaCl}$ in case of $V$. parahaemolyticus to enumerate total mesophilic bacteria.

\subsection{Statistical analysis}

The experiment consisted of three independently replicated trials $(n=3)$ and each reported value is the mean viable count \pm standard deviation (SD) of the results of three replicate treatments per experimental trial. An analysis of variance, using the mixed-effects procedure for bacterial counts, was conducted with SAS software (SAS Institute, 2011). Clam or mussel, strong or weak AEW, depuration time and selectivity of culture media were treated as fixed effects. Subjects were random samples from the target population and, therefore, were treated as random effects in the model. The interaction among fixed-effect variables was analyzed. The Kenward and Roger method was used to evaluate the denominator degrees of freedom $($ Kenward-Roger $=$ DDFM). In order to adjust the estimated standard deviations for fixed effects and interaction effects (Littell et al., 2006), the level of significance was set at a $P$ value of $<0.05$. Post hoc multiple pairwise comparisons of treatment group means were performed with the Tukey-Kramer adjustment (Tukey's honestly significant difference test) to control the type I error rate. 


\section{Results and discussion}

To our knowledge, this is the first study on the antimicrobial activity of AEW against five different bacterial species that were separately inoculated into live clam and mussel and for depuration times of only 1 and $2 \mathrm{~h}$. Table 1 shows the viable counts of E. coli O104:H4 in live clam and mussel after being treated with $1 \% \mathrm{NaCl}$, SAEW or WAEW for 1 or $2 \mathrm{~h}$. It was observed that holding inoculated shellfish in sterile saline solutions $(1 \% \mathrm{NaCl})$ for $2 \mathrm{~h}$ did not cause a significant reduction in the level of inoculated bacteria compared to the AEW treatments. SAEW (20 mg/L ACC) resulted in approximately $1.4 \log _{10} \mathrm{CFU} / \mathrm{g}$ reduction in the count after treatment for $1 \mathrm{~h}$ and about $1.6 \log _{10} \mathrm{CFU} / \mathrm{g}$ reduction after treatment for $2 \mathrm{~h}$ in clam. Although the increase in reduction by extending the treatment time from $1 \mathrm{~h}$ to $2 \mathrm{~h}$ was only $0.2 \log _{10} \mathrm{CFU} / \mathrm{g}$, it was statistically significant $(P<0.05)$. In comparison, WAEW $(10 \mathrm{mg} / \mathrm{L} \mathrm{ACC})$ inflicted reductions in $E$. coli counts of 0.7 and $1.0 \log _{10} \mathrm{CFU} / \mathrm{g}$ after treatment for 1 and $2 \mathrm{~h}$, respectively. Nonetheless, this reduction was significantly less compared to SAEW treatment. The extent of bacterial injury as measured by the difference in viable counts of the organism on nonselective and selective culture media was approximately $0.2 \log _{10} \mathrm{CFU} / \mathrm{g}$. The same pattern of inhibition was observed for E. coli after treatment of mussel with SAEW and WAEW for 1 or $2 \mathrm{~h}$. About 1.6 and $1.7 \log _{10} \mathrm{CFU} / \mathrm{g}$ reduction in the organism was observed after treatment with SAEW for 1 and $2 \mathrm{~h}$, respectively. However, WAEW resulted in larger reduction in $E$. coli counts $\left(0.9-1.1 \log _{10} \mathrm{CFU} / \mathrm{g}\right)$ compared to the level of reduction in clam (0.7-1.0) after 1 and $2 \mathrm{~h}$ treatment times, respectively. Also, it is worthwhile to mention that WAEW resulted in significantly $(P<0.05)$ less inactivation, yet more cells were injured (0.3-0.6 $\left.\log _{10} \mathrm{CFU} / \mathrm{g}\right)$ compared to SAEW.

Table 2 shows the viable counts of L. monocytogenes in live clam and mussel after treatment with $1 \% \mathrm{NaCl}, \mathrm{SAEW}$ or WAEW for 1 or $2 \mathrm{~h}$. Saline treatment did not elicit a noticeable 
253 reduction in L. monocytogenes count compared to the untreated control $(0 \mathrm{~h})$. SAEW resulted in 254 approximately 1.0 and $1.3 \log _{10} \mathrm{CFU} / \mathrm{g}$ reduction in clam after 1 and $2 \mathrm{~h}$ treatment times, 255 respectively. While WAEW resulted in about 0.7 and $0.8 \log _{10}$ CFU/g reduction in L. monocytogens 256 count after1 and $2 \mathrm{~h}$ treatment times, respectively. Longer treatment time $(2 \mathrm{~h})$ resulted in 257 significantly $(P<0.05)$ larger reduction compared to the $1 \mathrm{~h}$ treatment time. The extent of $L$. 258 monocytogenes injury in treated clam ranged between 0.1-0.2 $\log _{10} \mathrm{CFU} / \mathrm{g}$ in both SAEW and 259 WAEW. Likewise, the same pattern of L. monocytogenes inhibition was observed in treated 260 mussel. Treatment with $1 \% \mathrm{NaCl}$ had a marginal inhibitory activity against L. monocytogens. In 261 comparison, SAEW posed significantly $(P<0.05)$ larger inactivation compared with WAEW, 262 where it elicited about 1.3-1.6 $\log _{10} \mathrm{CFU} / \mathrm{g}$ reduction in the viable count. The level of $L$. 263 monocytogenes injury ranged between 0.2 and $0.3 \log _{10} \mathrm{CFU} / \mathrm{g}$.

264 Table 3 shows the inhibitory activity and AEW induced bacterial injury against $A$. 265 hydrophila in clam and mussel. SAEW resulted in approximately $1.4-1.6 \log _{10} \mathrm{CFU} / \mathrm{g}$ reduction, 266 whereas, WAEW resulted in about 0.7-1.3 $\log _{10}$ CFU/g reduction in A. hydrophila viable count in 267 the treated clam, in which SAEW resulted in significantly $(P<0.05)$ higher reduction compared to 268 WAEW. For mussel, SAEW resulted in approximately $1.3-1.5 \log _{10} \mathrm{CFU} / \mathrm{g}$ reduction in $A$. 269 hydrophila, which is significantly larger compared to the reduction induced by WAEW (0.6-0.7 $\left.270 \log _{10} \mathrm{CFU} / \mathrm{g}\right)$.

271 Table 4 shows the viable counts of $V$. parahaemolyticus in live clam and mussel after 272 treatment with $2 \% \mathrm{NaCl}$, SAEW or WAEW for 1 or $2 \mathrm{~h}$. Treatment with $2 \% \mathrm{NaCl}$ did not result in 273 a noticeable reduction in the level of $V$. parahaemolyticus viable count. In comparison, SAEW 274 elicited 1.3 to $1.5 \log _{10} \mathrm{CFU} / \mathrm{g}$ reduction, which was significantly $(P<0.05)$ larger compared to the 275 level of inhibition induced by WAEW (1.0-1.3 $\log _{10}$ CFU/g reduction) in the treated clam. In 
276 SAEW treated mussel, about 1.0 to $1.2 \log _{10} \mathrm{CFU} / \mathrm{g}$ reduction was obtained. WAEW resulted in 277 significantly $(P<0.05)$ less reduction $\left(0.7-0.9 \log _{10} \mathrm{CFU} / \mathrm{g}\right)$ in $V$. parahaemolyticus count 278 compared to SAEW. Also, it is worthwhile to mention that SAEW and WAEW resulted in 279 remarkably high level ( 0.4-0.9 $\left.\log _{10} \mathrm{CFU} / \mathrm{g}\right)$ of injured V. parahaemolyticus cells compared to 280 other bacteria investigated in the current study.

Table 5 shows the viable counts of $C$. jejuni in live clam and mussel after treatment with $1 \%$

$282 \mathrm{NaCl}, \mathrm{SAEW}$ or WAEW for 1 or $2 \mathrm{~h}$. Treatment with $1 \% \mathrm{NaCL}$ exhibited a significant $(P<0.05)$

283 reduction $\left(0.7-0.8 \log _{10} \mathrm{CFU} / \mathrm{g}\right)$ in the $C$. jejuni count compared to the untreated control $(0 \mathrm{~h})$. 284 SAEW resulted in about 1.5 to $1.7 \log _{10} \mathrm{CFU} / \mathrm{g}$ reduction, which was significantly $(P<0.05)$ larger 285 compared to the inhibitory effect of WAEW that resulted in only $0.8-1.0 \log _{10} \mathrm{CFU} / \mathrm{g}$ reduction in 286 the treated clam. Similarly, SAEW treated mussel resulted in a remarkable reduction level that 287 ranged between 2.1-2.2 $\log _{10} \mathrm{CFU} / \mathrm{g}$ in the $C$. jejuni count. In comparison, WAEW resulted in 288 significantly $(P<0.05)$ less inhibitory effect $\left(1.8-1.9 \log _{10}\right.$ CFU/g reduction) against $C$. jejuni 289 compared to SAEW. Notwithstanding, the level of AEW induced $C$. jejuni injury ranged between 0.2-0.5 $\log _{10} \mathrm{CFU} / \mathrm{g}$ in both types of shellfish.

In the current study treating shellfish with 1 or $2 \% \mathrm{NaCl}$ resulted only in a slight reduction 292 of all pathogens inoculated in clam and mussel. This marginal reduction is possibly due to the 293 physical removal of the pathogens off the shellfish. AEW usually exert antibacterial activity due to 294 its content of free chlorine and low pH. Furthermore, AEW possesses high ORP $(+950-+1150$ $295 \mathrm{mV}$ ), which is associated with greater oxidizing power and hence poses inhibitory activity 296 particularly against strict anaerobic and facultative anaerobes (Jay et al., 2005). In addition, AEW 297 inhibits bacteria by increasing the permeability of the cell membrane and therefore causing leakage 298 of intracellular constituents (Zeng et al., 2010). 
Generally, AEW is more effective as an antimicrobial treatment in pure microbial systems compared to food systems. The inhibitory effect of AEW was smaller against bacteria inoculated into shellfish as revealed in the current study compared to artificial broth media. A complete inhibitory effect of acidic and alkaline EO water against the same bacterial strains grown in artificial bacteriological broth (more than $7 \log _{10} \mathrm{CFU} / \mathrm{mL}$ reduction) within 6 min of $\mathrm{AEW}$ at $20^{\circ} \mathrm{C}$ was achieved (Ovissipour et al., 2015). The findings in the current study are consistent with previous studies reporting that EO water was highly effective against pathogens in suspension culture compared to food (Huang et al., 2006; Kim et al., 2000; Oomori et al., 2000; Park et al., 2002; Quan et al., 2010; Ren and Su, 2006; Venkitanarayanan et al., 1999). The Limited antibacterial activity is likely due to the presence of organic materials, primarily proteins and lipids that react with the free available chlorine forming combined chlorine that has much lower bactericidal activity than the free form. In this experiment, the bactericidal activity of AEW could have been minimized because of interactions between the AEW and organic components during filter feeding, which may result in reducing the activity of the AEW before the bacterial cells accumulated inside the digestive tract of the animals could be reached. Additionally, sanitizers usually exert stronger antimicrobial activity against pathogens existing on smoother surfaces. Hence, the irregular surfaces found in shellfish may provide a safe shelter for contaminating pathogens (Al-Holy et al., 2015).

In the current study, it is possible that the limiting factor for bactericidal activity might have been the ACC rather than treatment time. Huang et al. (2006) and Quan et al. (2010) reported that no further antibacterial activity was achieved by extending treatment time to kill $E$. coli and $V$. parahaemolyticus in cell suspension and inoculated seafood. However, the increase in chlorine concentration may cause deterioration and loss of quality of the perishable fish and shellfish, 
322 particularly in the situation tested here in which live shellfish were used. Ren and Su (2006)

323 indicated that treating inoculated raw oysters with EO water significantly reduced the level of $V$.

324 parahaemolyticus and $V$. vulnificus by $1.1 \log _{10} \mathrm{MPN} / \mathrm{g}$. However, they demonstrated that the

325 treatment process should be limited to a chlorine concentration of less than $30 \mathrm{mg} / \mathrm{L}$ and a

326 processing time of 4-6 h or less to avoid death of oysters. On the other hand, another study reported

327 that depuration with clean artificial seawater was not effective in reducing bacterial contamination

328 in treated oysters (Eyles and Davey, 1984; Ren and Su, 2006). Longer depuration period of oysters

329 (16 days) was required to elicit complete elimination of $V$. vulnificus spiked into oysters (Kelly and

330 Dinuzzo, 1985). In the current study, the used AEW was less effective against L. monocytogenes

331 compared to other pathogenic bacteria inoculated into shellfish. This is possibly because Gram

332 negative are generally more sensitive than Gram positive bacteria to AEW disinfection due to the

333 difference in cell wall structure (Jay et al., 2005).

334 However, one of the main benefits of using AEW in this study was the low chlorine levels

335 of less than $20 \mathrm{mg} / \mathrm{L}$. The tested residual chlorine content in flesh samples after $2 \mathrm{~h}$ of treatment

336 was less than $1.0 \mathrm{ppm}$. The US Environmental Protection Agency (EPA) has approved the use of

337 AEW in the food industry which makes the application of AEW in aquaculture is possible. Using

338 chlorine solutions at levels of $20 \mathrm{mg} / \mathrm{L}$ or less would be recognized as a safe usage level (GRAS).

339 Codex permits up to $20 \mathrm{mg} / \mathrm{L}$ chlorine in water that comes in contact with fish and fish products

340 and up to $100 \mathrm{mg} / \mathrm{L}$ in water used in cleaning and sanitation of equipment and facilities, however,

341 when chlorinated water used in the seafood industry; the residual chlorine level should not exceed

342 that of potable water (Food and Agriculture Organization of the United Nations (FAO) and World

343 Health Organization (WHO), 2000, 2008). Additionally, beside treatment with AEW water, other

344 hurdles (e.g., mild heat and UV treatments) can be applied to effectively control bacterial 
345 contamination in fish and fishery products (Kasai et al., 2011; Shiroodi et al., 2016; Xie at al., 346 2012).

347 In conclusion, this study showed that AEW with ACC of 10-20 mg/L could be used to 348 substantially reduce the level of contamination of common bacterial pathogens in live clam and 349 mussel within a depuration time of $2 \mathrm{~h}$. Although both of SAEW and WAEW were effective in 350 reducing the level of pathogens inoculated in clam and mussel, SAEW inflicted larger inhibitory 351 effect. Therefore, the use of AEW may help control possible unhygienic practices during production 352 and processing of shellfish without apparent deterioration in the quality.

\section{Acknowledgments}

354 This research was supported by Agricultural Research Center at Washington State University, the 355 University of Jordan and USDA-NIFA 2011-68003-20096.

\section{References}

357 Al-Holy, M.A., Rasco, B.A., 2015. The bactericidal activity of acidic electrolyzed oxidizing water 358 against Escherichia coli O157:H7, Salmonella Typhimurium, and Listeria monocytogenes on raw fish, chicken and beef surfaces. Food Control 54, 317-321.

360 Almeida, C., Soares, F., 2012. Microbiological monitoring of bivalves from the Ria Formosa Lagoon (south coast of Portugal): A 20 years of sanitary survey. Marine Pollution Bulletin 64, $252-262$.

Al-Qadiri, H.M., Lu, X., Al-Alami, N.I., Rasco, B., 2011. Survival of Escherichia coli O157:H7 and Campylobacter jejuni in bottled purified drinking water under different storage conditions. Journal of Food Protection 74, 254-260. 
Al-Qadiri, H.M., Sablani, S.S., Ovissipour, M., Al-Alami, N., Govindan, B., Rasco, B., 2015. Effect of oxygen stress on growth and survival of Clostridium perfringens, Campylobacter jejuni, and Listeria monocytogenes under different storage conditions. Journal of Food Protection 78, 691 697.

Anacleto, P., Pedro, S., Nunes, M.L., Rosa, R., Marques, A., 2013. Microbiological composition of native and exotic clams from Tagus estuary: Effect of season and environmental parameters. Marine Pollution Bulletin 74, 116-124.

Astorga, A.F, Alonso, R., 2010. Campylobacter jejuni. In: Liu, D. (Ed.), Molecular Detection of Foodborne Pathogens. CRC Press, Boca Raton, FL, pp. 345-360.

Croci, L., Losio, M.N., Suffredini, E., Pavoni, E., Di Pasquale, S., Fallacara, F., Arcangeli, G., 2007. Assessment of human enteric viruses in shellfish from the northern Adriatic sea. International Journal of Food Microbiology 114, 252-257.

Eyles, M.J., Davey, G.R., 1984. Microbiology of commercial depuration of the Sydney rock oyster, Crassostrea commercialis. Journal of Food Protection 47, 703-706.

Food and Agriculture Organization of the United Nations (FAO), World Health Organization (WHO), 2000. Codex Alimentarius Commission, Joint FAO/WHO Food Standards Programme, Codex Committee on Fish and Fishery Products, Discussion Paper on the use of Chlorinated Water. Twenty-fourth Session, Alesund, Norway. Available at: ftp://ftp.fao.org/codex/Meetings/CCFFP/ccffp24/fp00_13e.pdf 
Food and Agriculture Organization of the United Nations (FAO), World Health Organization (WHO), 2008. Codex Alimentarius Commission, Joint FAO/WHO Food Standards Programme, Report of the Twenty-Ninth Session of the Codex Committee on Fish and Fishery Products. Thirty-first Session, Trondheim, Norway. Available at: file:///C:/Users/Dr\%20Al\%20Qadiri/Downloads/al31_18e\%20(1).pdf

Hara-Kudo, Y., Nishina, T., Nakagawa, H., Konuma, H., Hasegawa, J., Kumagai, S., 2001. Improved method for detection of Vibrio parahaemolyticus in seafood. Applied and Environmental Microbiology 67, 5819-5823.

Hsu, S.Y., 2003. Effects of water flow rate, salt concentration and water temperature on efficiency of an electrolyzed oxidizing water generator. Journal of Food Engineering 60, 469473.

Huang, Y.R., Hsiech, H.S., Lin, S.Y., Lin, S.J., Hung, Y-C., Hwang, D.F., 2006. Application of electrolyzed oxidizing water on the reduction of bacterial contamination for seafood. Food Control 17, 987-993.

Innes, D.J., Bates, J.A., 1999. Morphological variation of Mytilus edulis and Mytilus trossulus in eastern Newfoundland. Marine Biology 133, 691-699.

Jay, J.M., Loessner, M J., Golden, D.A., 2005. Modern Food Microbiology, 7th ed. New York, Springer, pp. 312-314.

Kasai, H., Ishikawa, A., Hori, Y., Watanabe, K., Yoshimizu, M., 2000. Disinfectant effects of electrolyzed salt water on fish pathogenic bacteria and viruses. Nippon Suisan Gakkaishi 66, 1020-1025 (in Japanese, with English abstract). 
Kelly, M.T., Dinuzzo, A., 1985. Uptake and clearance of Vibrio vulnificus from Gulf coast oysters (Crassostrea virginica). Applied Environment Microbiology 50, 1548-1549.

Kim, C., Hung, Y.-C., Brackett, R. E., 2000. Efficacy of electrolyzed oxidizing (EO) and chemically modified water on different types of foodborne pathogens. International Journal of Food Microbiology 61, 199-207.

Lees, D., Younger, A., Dore, B., 2010. Depuration and relaying. In: Rees, G., Pond, K., Kay, D., Bartram, J., Santo Domingo, J. (Eds.), Safe Management of Shellfish and Harvest Waters. World Health Organization (WHO), IWA Publishing, London, pp. 145-181. Available at: http://www.who.int/water_sanitation_health/emerging/depuration.pdf

Littell, R.C., Milliken, G.A., Stroup, W.W, Wolfinger, R.D., Schabenberger, O., 2006. SAS for mixed models, 2nd ed. SAS Institute Inc., Cary, NC.

Liu, D., Busse, H.J., 2010. Listeria. In: Liu, D. (Ed.), Molecular Detection of Foodborne Pathogens. CRC Press, Boca Raton, FL, pp. 207-220.

Love, D. C., Lovelace, G. L., Sobsey, M. D., 2010. Removal of Escherichia coli, Enterococcus fecalis, coliphage MS2, poliovirus, and hepatitis A virus from oysters (Crassostrea virginica) and hard shell clams (Mercinaria mercinaria) by depuration. International Journal of Food Microbiology 143, 211-217.

Newton, A.E., Garrett, N., Stroika, S.G., Halpin, J.L., Turnsek, M., Mody, R.K., 2014. Notes from the field: increase in Vibrio parahaemolyticus infections associated with consumption of atlantic coast shellfish-2013. MMWR Morb. Mortal. Wkly. Rep 63, 335-336. Available at: http://www.cdc.gov/mmwr/preview/mmwrhtml/mm6315a6.htm 
Oliveira, J., Cunha, A., Castilho, F., Romalde, J.L., Pereira, M.J., 2011. Microbial contamination and purification of bivalve shellfish: crucial aspects in monitoring and future perspectives e a mini-review. Food Control 22, 805-816.

Oomori, T., Oka, T., Inuta, T., Arata, Y., 2000. The efficiency of disinfection of acidic electrolyzed water in the presence of organic materials. Analytical Science 16, 365-369.

Ovissipour, M., Al-Qadiri, H.M., Sablani, S.S., Govindan, B.N., Al-Alami, N., Rasco, B., 2015. Efficacy of acidic and alkaline electrolyzed water for inactivating Escherichia coli O104:H4, Listeria monocytogenes, Campylobacter jejuni, Aeromonas hydrophila, and Vibrio parahaemolyticus in cell suspensions. Food Control 53, 117-123.

Ovissipour, M., Rasco, B., Tang, J., Sablani, S.S., 2013. Kinetics of quality changes in whole blue mussel (Mytilus edulis) during pasteurization. Food Research International 53, 141-148.

Park, H., Hung, Y.-C., Brackett, R.E., 2002. Antimicrobial effect of electrolyzed water for inactivating Campylobacter jejuni during poultry washing. International Journal of Food Microbiology 72, 77-83.

Park, K.I., Paillard, C., Chevalier, P.L., Choi, K.S., 2006. Report on the occurrence of brown ring disease (BRD) in Manila clam, Ruditapes philippinarum, on the west coast of Korea. Aquaculture 255, 610-613.

Quan, Y., Choi, K.D., Chung, D., Shin, I.S., 2010. Evaluation of bactericidal activity of weakly acidic electrolyzed water (WAEW) against Vibrio vulnificus and Vibrio parahaemolyticus. International Journal of Food Microbiology 136, 255-260.

Reilly, A., Käferstein, F., 1997. Food safety hazards and the application of the principles of hazard analysis and critical control point (HACCP) system for their control in aquaculture production. Aquaculture Research 28, 735-752. 
453 Ren, T., Su, Y.-C., 2006. Effects of electrolyzed oxidizing water treatment on reducing Vibrio $454 \quad$ parahaemolyticus and Vibrio vulnificus in raw oysters. Journal of Food Protection 69, 18291834.

456 SAS Institute, 2011. The SAS system for Windows. Release 9.2.SASInstitute Inc., Cary, NC.

457 Schulze, A.D., Alabi, A.O., Tattersall-Sheldrake, A.R., Miller, K.M., 2006. Bacterial diversity in a 458 marine hatchery: Balance between pathogenic and potentially probiotic bacterial strains. $459 \quad$ Aquaculture 256, 50-73.

460 Shiroodi, S.G., Ovissipour, M., Ross, C.F., Rasco, B.A., 2016. Efficacy of electrolyzed oxidizing 461

Venkitanarayanan, K.S., Ezeike, G.O., Hung, Y.-C., Doyle, M., 1999. Efficacy of electrolyzed oxidizing water for inactivating Escherichia coli O157:H7, Salmonella enteritidis, and Listeria monocytogenes. Applied and Environmental Microbiology 65, 4276-4279. water as a pretreatment method for reducing Listeria monocytogenes contamination in cold smoked Atlantic salmon (Salmo salar). Food Control 60, 401-407.

467

Zeng, X., Tang, W., Ye, G., Ouyang, T., Tian, L., Ni, Y., Li, P., 2010. Studies on disinfection mechanism of electrolyzed oxidizing water on Escherichia coli and Staphylococcus aureus. Journal of Food Science 75, M253-260.

469 Warburton, D.W., McCormick, J.K., Bowen, B., 1994. Survival and recovery of Aeromonas 470 hydrophila in water: development of methodology for testing bottled water in Canada. $471 \quad$ Canadian Journal of Microbiology 40, 145-148.

472 Xie, J., Sun, X., Pan, Y., Zhao, Y., 2012. Combining basic electrolyzed water pretreatment and mild 473 heat greatly enhanced the efficacy of acidic electrolyzed water against Vibrio $474 \quad$ parahaemolyticus on shrimp. Food Control 23, 320-324. 
475 Zhang, L., Yang, D., Wang, Q., Yuan, Z., Wu, H., Pei, D., Cong, M., Li, F., Ji, C., Zhao, J., 2015. A

476 defensin from clam Venerupis philippinarum: Molecular characterization, localization,

477 antibacterial activity, and mechanism of action. Developmental and Comparative Immunology

$478 \quad 51,29-38$.

479

480

481

482

483

484

485

486

487

488

489

490

491

492 
Table 1

494 Mean viable counts of E. coli O104:H4 $\left(\log _{10} \mathrm{CFU} / \mathrm{g}\right)^{1,2}$ inoculated into live clam and mussel

\begin{tabular}{|c|c|c|c|c|}
\hline \multirow[t]{3}{*}{ Treatment } & \multicolumn{4}{|c|}{ Treatment time $(\mathrm{h})$} \\
\hline & \multicolumn{2}{|c|}{1} & \multicolumn{2}{|c|}{2} \\
\hline & Nonselective media & Selective media & Nonselective media & Selective media \\
\hline \multicolumn{5}{|l|}{$\mathrm{Clam}^{3}$} \\
\hline$(1 \% \mathrm{NaCl})$ & $\begin{array}{c}5.6 \pm 0.1^{\mathrm{a}} \\
(0.1)\end{array}$ & $\begin{array}{c}5.6 \pm 0.1^{\mathrm{a}} \\
\quad(0.1)\end{array}$ & $\begin{array}{c}5.6 \pm 0.1^{\mathrm{a}} \\
\quad(0.1)\end{array}$ & $\begin{array}{c}5.6 \pm 0.0^{\mathrm{a}} \\
\quad(0.1)\end{array}$ \\
\hline SAEW & $\begin{array}{c}4.3 \pm 0.0^{\mathrm{e}} \\
\quad(1.4)\end{array}$ & $\begin{array}{c}4.2 \pm 0.1^{\mathrm{f}} \\
\quad(1.5)\end{array}$ & $\begin{array}{c}4.1 \pm 0.1^{\mathrm{f}} \\
\quad(1.6)\end{array}$ & $\begin{array}{c}3.9 \pm 0.0^{\mathrm{g}} \\
\quad(1.8)\end{array}$ \\
\hline WAEW & $\begin{array}{c}5.0 \pm 0.1^{b} \\
(0.7)\end{array}$ & $\begin{array}{c}4.8 \pm 0.1^{\mathrm{c}} \\
\quad(0.9)\end{array}$ & $\begin{array}{c}4.7 \pm 0.0^{\mathrm{c}} \\
\quad(1.0)\end{array}$ & $\begin{array}{c}4.5 \pm 0.0^{\mathrm{d}} \\
\quad(1.2)\end{array}$ \\
\hline \multicolumn{5}{|l|}{ Mussel $^{4}$} \\
\hline$(1 \% \mathrm{NaCl})$ & $\begin{array}{c}5.4 \pm 0.0^{\mathrm{a}} \\
\quad(0.0)\end{array}$ & $\begin{array}{c}5.4 \pm 0.0^{\mathrm{a}} \\
\quad(0.0)\end{array}$ & $\begin{array}{c}5.3 \pm 0.1^{\mathrm{a}} \\
\quad(0.1)\end{array}$ & $\begin{array}{c}5.3 \pm 0.1^{\mathrm{a}} \\
\quad(0.1)\end{array}$ \\
\hline SAEW & $\begin{array}{c}3.8 \pm 0.1^{\text {ef }} \\
(1.6)\end{array}$ & $\begin{array}{c}3.6 \pm 0.1^{\mathrm{gh}} \\
(1.8)\end{array}$ & $\begin{array}{c}3.7 \pm 0.0^{\mathrm{fg}} \\
\quad(1.7)\end{array}$ & $\begin{array}{c}3.5 \pm 0.1^{\mathrm{h}} \\
\quad(1.9)\end{array}$ \\
\hline WAEW & $\begin{array}{c}4.5 \pm 0.0^{b} \\
(0.9)\end{array}$ & $\begin{array}{c}3.9 \pm 0.1^{\mathrm{de}} \\
(1.5)\end{array}$ & $\begin{array}{c}4.3 \pm 0.0^{\mathrm{c}} \\
(1.1)\end{array}$ & $\begin{array}{c}4.0 \pm 0.1^{\mathrm{d}} \\
(1.4)\end{array}$ \\
\hline
\end{tabular}

495

496

497

498

499

500

501

502
503

504

505

506

507

508

${ }^{\mathrm{T}}$ Values are the means of three independent replicate trials \pm standard deviation, with $\log _{10}$ reductions (expressed in $\mathrm{CFU} / \mathrm{g}$ ) presented in parentheses.

${ }^{2}$ For each studied animal, treatment means without shared superscripts are significantly different (Tukey's HSD test, $P<0.05$ ).

${ }^{3,4}$ Mean viable counts of the inoculated untreated controls $(0 \mathrm{~h}): 5.7$ and $5.4 \log _{10} \mathrm{CFU} / \mathrm{g}$ for clam and mussel, respectively, and which selected as " $a$ " in statistical analysis. 
Table 2

510 Mean viable counts of L. monocytogenes $\left(\log _{10} \mathrm{CFU} / \mathrm{g}\right)^{1,2}$ inoculated into live clam and mussel

\begin{tabular}{|c|c|c|c|c|}
\hline \multirow[t]{3}{*}{ Treatment } & \multicolumn{4}{|c|}{ Treatment time $(\mathrm{h})$} \\
\hline & \multicolumn{2}{|c|}{1} & \multicolumn{2}{|c|}{2} \\
\hline & Nonselective media & Selective media & Nonselective media & Selective media \\
\hline \multicolumn{5}{|l|}{$\mathrm{Clam}^{3}$} \\
\hline$(1 \% \mathrm{NaCl})$ & $\begin{array}{c}4.8 \pm 0.1^{b} \\
(0.2)\end{array}$ & $\begin{array}{c}4.7 \pm 0.0^{b} \\
(0.3)\end{array}$ & $\begin{array}{c}4.7 \pm 0.1^{b} \\
(0.3)\end{array}$ & $\begin{array}{c}4.7 \pm 0.0^{b} \\
(0.3)\end{array}$ \\
\hline SAEW & $\begin{array}{c}4.0 \pm 0.0^{\mathrm{d}} \\
\quad(1.0)\end{array}$ & $\begin{array}{c}3.7 \pm 0.1^{\mathrm{e}} \\
\quad(1.3)\end{array}$ & $\begin{array}{c}3.7 \pm 0.0^{\mathrm{ef}} \\
(1.3)\end{array}$ & $\begin{array}{c}3.6 \pm 0.1^{\mathrm{f}} \\
(1.4)\end{array}$ \\
\hline WAEW & $\begin{array}{c}4.2 \pm 0.1^{\mathrm{c}} \\
(0.8)\end{array}$ & $\begin{array}{c}4.1 \pm 0.0^{\mathrm{cd}} \\
(0.9)\end{array}$ & $\begin{array}{c}4.2 \pm 0.1^{\mathrm{c}} \\
(0.8)\end{array}$ & $\begin{array}{c}4.0 \pm 0.0^{\mathrm{d}} \\
\quad(1.0)\end{array}$ \\
\hline \multicolumn{5}{|l|}{$\underline{\text { Mussel }^{4}}$} \\
\hline$(1 \% \mathrm{NaCl})$ & $\begin{array}{c}5.4 \pm 0.1^{\mathrm{a}} \\
\quad(0.1)\end{array}$ & $\begin{array}{c}5.4 \pm 0.0^{\mathrm{a}} \\
\quad(0.1)\end{array}$ & $\begin{array}{c}5.2 \pm 0.1^{b} \\
(0.3)\end{array}$ & $\begin{array}{c}5.1 \pm 0.0^{b} \\
\quad(0.4)\end{array}$ \\
\hline SAEW & $\begin{array}{c}4.2 \pm 0.1^{\mathrm{f}} \\
(1.3)\end{array}$ & $\begin{array}{c}4.0 \pm 0.0^{\mathrm{g}} \\
(1.5)\end{array}$ & $\begin{array}{c}3.9 \pm 0.0^{\mathrm{g}} \\
\quad(1.6)\end{array}$ & $\begin{array}{c}3.5 \pm 0.1^{\mathrm{h}} \\
\quad(2.0)\end{array}$ \\
\hline WAEW & $\begin{array}{c}4.9 \pm 0.0^{c} \\
(0.6)\end{array}$ & $\begin{array}{c}4.6 \pm 0.1^{\mathrm{d}} \\
(0.9)\end{array}$ & $\begin{array}{c}4.6 \pm 0.1^{\mathrm{d}} \\
(0.9)\end{array}$ & $\begin{array}{c}4.4 \pm 0.0^{\mathrm{e}} \\
(1.1)\end{array}$ \\
\hline
\end{tabular}

511

512

513

514

515

516

517

518

519

520

521

522

523

524 
Table 3

526 Mean viable counts of $A$. hydrophila $\left(\log _{10} \mathrm{CFU} / \mathrm{g}\right)^{1,2}$ inoculated into live clam and mussel

\begin{tabular}{|c|c|c|c|c|}
\hline \multirow[t]{3}{*}{ Treatment } & \multicolumn{4}{|c|}{ Treatment time $(\mathrm{h})$} \\
\hline & \multicolumn{2}{|c|}{1} & \multicolumn{2}{|c|}{2} \\
\hline & Nonselective media & Selective media & Nonselective media & Selective media \\
\hline \multicolumn{5}{|l|}{$\mathrm{Clam}^{3}$} \\
\hline$(1 \% \mathrm{NaCl})$ & $\begin{array}{c}5.4 \pm 0.1^{b} \\
(0.3)\end{array}$ & $\begin{array}{c}5.4 \pm 0.0^{b} \\
(0.3)\end{array}$ & $\begin{array}{c}5.3 \pm 0.1^{b} \\
(0.4)\end{array}$ & $\begin{array}{c}5.3 \pm 0.0^{b} \\
(0.4)\end{array}$ \\
\hline SAEW & $\begin{array}{c}4.3 \pm 0.1^{\mathrm{ef}} \\
(1.4)\end{array}$ & $\begin{array}{c}4.1 \pm 0.1^{\mathrm{f}} \\
\quad(1.6)\end{array}$ & $\begin{array}{c}4.1 \pm 0.1^{\mathrm{f}} \\
\quad(1.6)\end{array}$ & $\begin{array}{c}3.8 \pm 0.0^{\mathrm{g}} \\
\quad(1.9)\end{array}$ \\
\hline WAEW & $\begin{array}{c}5.0 \pm 0.0^{c} \\
(0.7)\end{array}$ & $\begin{array}{c}4.4 \pm 0.1^{\mathrm{de}} \\
(1.3)\end{array}$ & $\begin{array}{c}4.4 \pm 0.3^{\mathrm{d}} \\
(1.3)\end{array}$ & $\begin{array}{c}4.3 \pm 0.1^{\mathrm{ef}} \\
(1.4)\end{array}$ \\
\hline \multicolumn{5}{|l|}{$\underline{\text { Mussel }^{4}}$} \\
\hline$(1 \% \mathrm{NaCl})$ & $\begin{array}{c}5.4 \pm 0.1^{\mathrm{a}} \\
\quad(0.0)\end{array}$ & $\begin{array}{c}5.3 \pm 0.1^{\mathrm{a}} \\
\quad(0.1)\end{array}$ & $\begin{array}{c}5.3 \pm 0.1^{\mathrm{a}} \\
(0.1)\end{array}$ & $\begin{array}{c}5.2 \pm 0.1^{\mathrm{a}} \\
\quad(0.2)\end{array}$ \\
\hline SAEW & $\begin{array}{c}4.1 \pm 0.1^{\mathrm{e}} \\
\quad(1.3)\end{array}$ & $\begin{array}{c}3.8 \pm 0.1^{f} \\
(1.6)\end{array}$ & $\begin{array}{c}3.9 \pm 0.0^{\mathrm{f}} \\
(1.5)\end{array}$ & $\begin{array}{c}3.5 \pm 0.0^{\mathrm{g}} \\
\quad(1.9)\end{array}$ \\
\hline WAEW & $\begin{array}{c}4.8 \pm 0.0^{b} \\
(0.6)\end{array}$ & $\begin{array}{c}4.5 \pm 0.1^{\mathrm{c}} \\
(0.9)\end{array}$ & $\begin{array}{c}4.7 \pm 0.1^{b} \\
(0.7)\end{array}$ & $\begin{array}{c}4.3 \pm 0.0^{\mathrm{d}} \\
(1.1)\end{array}$ \\
\hline
\end{tabular}

${ }^{\mathrm{T}}$ Values are the means of three independent replicate trials \pm standard deviation, with $\log _{10}$

5292 For each studied animal, treatment means without shared superscripts are significantly different 530 (Tukey's HSD test, $P<0.05$ ).

531 ${ }^{3,4}$ Mean viable counts of the inoculated untreated controls $(0 \mathrm{~h}): 5.7$ and $5.4 \log _{10} \mathrm{CFU} / \mathrm{g}$ for clam and mussel, respectively, and which selected as " $a$ " in statistical analysis. 
Table 4

542 Mean viable counts of $V$. parahaemolyticus $\left(\log _{10} \mathrm{CFU} / \mathrm{g}\right){ }^{1,2}$ inoculated into live clam and mussel

\begin{tabular}{|c|c|c|c|c|}
\hline \multirow[t]{3}{*}{ Treatment } & \multicolumn{4}{|c|}{ Treatment time $(\mathrm{h})$} \\
\hline & \multicolumn{2}{|c|}{1} & \multicolumn{2}{|c|}{2} \\
\hline & Nonselective media & Selective media & Nonselective media & Selective media \\
\hline \multicolumn{5}{|l|}{$\mathrm{Clam}^{3}$} \\
\hline$(2 \% \mathrm{NaCl})$ & $\begin{array}{c}5.2 \pm 0.1^{\mathrm{ab}} \\
\quad(0.1)\end{array}$ & $\begin{array}{c}5.1 \pm 0.1^{\mathrm{ab}} \\
\quad(0.2)\end{array}$ & $\begin{array}{c}5.1 \pm 0.1^{b} \\
(0.2)\end{array}$ & $\begin{array}{c}5.1 \pm 0.0^{b} \\
\quad(0.2)\end{array}$ \\
\hline SAEW & $\begin{array}{c}4.0 \pm 0.0^{\mathrm{d}} \\
\quad(1.3)\end{array}$ & $\begin{array}{c}3.9 \pm 0.0^{\mathrm{ef}} \\
(1.4)\end{array}$ & $\begin{array}{c}3.8 \pm 0.1^{\mathrm{f}} \\
(1.5)\end{array}$ & $\begin{array}{c}3.6 \pm 0.1^{\mathrm{g}} \\
(1.7)\end{array}$ \\
\hline WAEW & $\begin{array}{c}4.3 \pm 0.1^{\mathrm{c}} \\
(1.0)\end{array}$ & $\begin{array}{c}4.1 \pm 0.0^{\mathrm{d}} \\
\quad(1.2)\end{array}$ & $\begin{array}{c}4.0 \pm 0.1^{\mathrm{de}} \\
(1.3)\end{array}$ & $\begin{array}{c}3.9 \pm 0.0^{\mathrm{de}} \\
(1.4)\end{array}$ \\
\hline \multicolumn{5}{|l|}{$\underline{\text { Mussel }^{4}}$} \\
\hline$(2 \% \mathrm{NaCl})$ & $\begin{array}{c}5.0 \pm 0.1^{\mathrm{a}} \\
\quad(0.1)\end{array}$ & $\begin{array}{c}5.0 \pm 0.1^{\mathrm{a}} \\
\quad(0.1)\end{array}$ & $\begin{array}{c}5.0 \pm 0.0^{\mathrm{a}} \\
\quad(0.1)\end{array}$ & $\begin{array}{c}4.9 \pm 0.0^{\mathrm{a}} \\
\quad(0.2)\end{array}$ \\
\hline SAEW & $\begin{array}{c}4.1 \pm 0.1^{\mathrm{cd}} \\
\quad(1.0)\end{array}$ & $\begin{array}{c}3.2 \pm 0.1^{\mathrm{g}} \\
(1.9)\end{array}$ & $\begin{array}{c}3.9 \pm 0.1^{\mathrm{ef}} \\
(1.2)\end{array}$ & $\begin{array}{c}3.0 \pm 0.1^{\mathrm{h}} \\
\quad(2.1)\end{array}$ \\
\hline WAEW & $\begin{array}{c}4.4 \pm 0.0^{\mathrm{b}} \\
(0.7)\end{array}$ & $\begin{array}{c}4.0 \pm 0.0^{\mathrm{de}} \\
(1.1)\end{array}$ & $\begin{array}{c}4.2 \pm 0.1^{\mathrm{c}} \\
(0.9)\end{array}$ & $\begin{array}{c}3.8 \pm 0.1^{\mathrm{f}} \\
(1.3)\end{array}$ \\
\hline
\end{tabular}

$543{ }^{T}$ Values are the means of three independent replicate trials \pm standard deviation, with $\log _{10}$ 544 reductions (expressed in $\mathrm{CFU} / \mathrm{g}$ ) presented in parentheses.

$545{ }^{2}$ For each studied animal, treatment means without shared superscripts are significantly different 546 (Tukey's HSD test, $P<0.05$ ).

$547{ }^{3,4}$ Mean viable counts of the inoculated untreated controls $(0 \mathrm{~h}): 5.3$ and $5.1 \log _{10} \mathrm{CFU} / \mathrm{g}$ for clam 548 and mussel, respectively, and which selected as " $a$ " in statistical analysis.

549

550

551

552

553

554

555 
557 Mean viable counts of $C$. jejuni $\left(\log _{10} \mathrm{CFU} / \mathrm{g}\right)^{1,2}$ inoculated into live clam and mussel

\begin{tabular}{|c|c|c|c|c|}
\hline \multirow[t]{3}{*}{ Treatment } & \multicolumn{4}{|c|}{ Treatment time $(\mathrm{h})$} \\
\hline & \multicolumn{2}{|c|}{1} & \multicolumn{2}{|c|}{2} \\
\hline & Nonselective media & Selective media & Nonselective media & Selective media \\
\hline \multicolumn{5}{|l|}{$\mathrm{Clam}^{3}$} \\
\hline$(1 \% \mathrm{NaCl})$ & $\begin{array}{c}4.2 \pm 0.0^{\mathrm{b}} \\
\quad(0.7)\end{array}$ & $\begin{array}{c}4.1 \pm 0.1^{\mathrm{b}} \\
\quad(0.8)\end{array}$ & $\begin{array}{c}4.1 \pm 0.0^{b} \\
\quad(0.8)\end{array}$ & $\begin{array}{c}4.0 \pm 0.1^{b} \\
(0.9)\end{array}$ \\
\hline SAEW & $\begin{array}{c}3.4 \pm 0.1^{\mathrm{f}} \\
(1.5)\end{array}$ & $\begin{array}{c}3.1 \pm 0.1^{\mathrm{g}} \\
(1.8)\end{array}$ & $\begin{array}{c}3.2 \pm 0.0^{\mathrm{fg}} \\
(1.7)\end{array}$ & $\begin{array}{c}2.8 \pm 0.1^{\mathrm{h}} \\
\quad(2.1)\end{array}$ \\
\hline WAEW & $\begin{array}{c}4.1 \pm 0.1^{\mathrm{c}} \\
(0.8)\end{array}$ & $\begin{array}{c}3.9 \pm 0.1^{\mathrm{d}} \\
(1.0)\end{array}$ & $\begin{array}{c}3.9 \pm 0.0^{\mathrm{d}} \\
(1.0)\end{array}$ & $\begin{array}{c}3.7 \pm 0.1^{\mathrm{e}} \\
(1.2)\end{array}$ \\
\hline \multicolumn{5}{|l|}{ Mussel $^{4}$} \\
\hline$(1 \% \mathrm{NaCl})$ & $\begin{array}{c}4.8 \pm 0.0^{b} \\
\quad(0.5)\end{array}$ & $\begin{array}{c}4.7 \pm 0.1^{b} \\
(0.6)\end{array}$ & $\begin{array}{c}4.7 \pm 0.0^{b} \\
(0.6)\end{array}$ & $\begin{array}{c}4.6 \pm 0.1^{b} \\
(0.7)\end{array}$ \\
\hline SAEW & $\begin{array}{c}3.2 \pm 0.0^{\mathrm{de}} \\
\quad(2.1)\end{array}$ & $\begin{array}{c}3.0 \pm 0.1^{\mathrm{f}} \\
(2.3)\end{array}$ & $\begin{array}{c}3.1 \pm 0.1^{\mathrm{f}} \\
(2.2)\end{array}$ & $\begin{array}{c}2.6 \pm 0.1^{\mathrm{g}} \\
\quad(2.7)\end{array}$ \\
\hline WAEW & $\begin{array}{c}3.5 \pm 0.1^{\mathrm{c}} \\
(1.8)\end{array}$ & $\begin{array}{c}3.3 \pm 0.1^{\mathrm{d}} \\
(2.0)\end{array}$ & $\begin{array}{c}3.4 \pm 0.1^{\mathrm{d}} \\
(1.9)\end{array}$ & $\begin{array}{c}3.2 \pm 0.1^{\text {ef }} \\
(2.1)\end{array}$ \\
\hline
\end{tabular}

572

573

574

${ }^{\mathrm{T}}$ Values are the means of three independent replicate trials \pm standard deviation, with $\log _{10}$ reductions (expressed in $\mathrm{CFU} / \mathrm{g}$ ) presented in parentheses.

${ }^{2}$ For each studied animal, treatment means without shared superscripts are significantly different (Tukey's HSD test, $P<0.05$ ).

${ }^{3,4}$ Mean viable counts of the inoculated untreated controls $(0 \mathrm{~h}): 4.9$ and $5.3 \log _{10} \mathrm{CFU} / \mathrm{g}$ for clam and mussel, respectively, and which selected as "a" in statistical analysis. 